\title{
A Research Study on How the Pandemic Enriched Higher Education System among Students
}

\author{
Haitham Hilal Al Busaidi ${ }^{1}$, Dr. Syed Aulia ${ }^{2}$ \\ ${ }^{I}$ MBA Student - Middle East Collage - Muscat, Sultanate of Oman \\ ${ }^{2}$ Faculty - Department of Management Studies, Middle East Collage - Muscat, Sultanate of Oman
}

*Corresponding Authors: Haitham Hilal Al Busaidi, MBA Student - Middle East Collage - Muscat, Sultanate of Oman

\begin{abstract}
The main aim of this study is to investigate the effect on students' and educators' in adopting of technology during the Covid-19 pandemic. Further, this study is aimed to get in depth concept of online learning, access to internet and infra structural challenges for students, their economic-social conditions, their viewpoints based on age, gender, and instruction, and the other being territorial or spatial contrasts such as the rural-urban class. A descriptive research design is used to conduct this research study; where in the primary data is collected from students through online questionnaire and interpreted through statistical calculations. This study recommends facilitating the learning process by the teachers to do both synchronous activities as well as asynchronous activities.
\end{abstract}

Keywords: Students, Online learning, Covid-19, Challenges.

\section{INTRODUCTION}

This study aims to investigate the effect of fear on students' and educators' adoption of technology during the COVID-19 pandemic. The information gathered during the research was analyzed. The study main hypotheses concern the impact of COVID-19, as well as the spread of COVID-19 of various types of fear. Fear of family isolation arose during the Corona virus pandemic. The most common threats that students and teachers face are fear of educational failure and fear of losing social relationships(Al-Amrani, Said Nasser; Harrington, Michael ;, 2020).

The spread of COVID-19 is a major challenge for education frameworks. This guide is always coordinated for teachers, heads of teaching and authorities on tackling the crisis. What arrangements should institutions make during the short period of time that they can reach, and how do they meet students' needs according to level and field of thought?

Reassuring students and parents are an important component of their response under these circumstances. To increase distance learning capacity, schools and colleges should take advantage of asynchronous learning, which works better within advanced field coordination. To expand on material that is considered familiar, the instructions should include the many tasks and activities that place COVID-19 in a verifiable global environment. When building the curriculum, planning to initially assess students makes a difference. Finally, this point of view suggests adaptive methods to repair damage to students' learning pathways once the proliferation ends and provides a list of assets.

Education is considered as an exchange of the values and amassed information of society it is comparable to what sociologists call socialization or culture. Instruction is outlined to direct them in learning culture, defining their behavior within the ways of adulthood, and coordinating them towards their ultimate role in society. Within the most primitive societies, there's regularly small formal learning - small of what one would ordinarily call a school, classroom, or instructor. Instep, the whole environment, and all exercises are frequently seen as school and numerous, or all grown-ups work as instructors. As social orders gotten to be more complex, the sum of information that will be exchanged from one era to the another gets to be more than anybody can know, and thus, more particular, and viable implies of transmitting culture must be created. The result is formal instruction the school and the pro called the educator. 
As per the Oman Observer, the online Situation is seen as the way forward to proceed higher instruction without disturbing the academic year. The ministry of Higher Education, research and innovation Instruction has set specifications for specialized colleges and private teach in this respect. A few private educate have set up their summer courses online within the wake of the Covid-19 outbreak, as the move has been so quick coming about not as it were in working from home. It is different from the traditional semester in that you just are selected and as it were going to a lesson at a certain time, and in case the understudy is missing from the semester that he has as of now missed. Connection with the coach is superior presently, too.(Magd, 2021)

Currently, in most universities and colleges in Oman and all over the world, all teachers are teaching from home. And everyone is wondering will online teaching continue even after the Covid-19 crisis?( Mishra, et al., 2020)

On the other hand, online education has gained popularity since the early 2000s. And in most countries today, some of the best universities in the world offer free courses to the public, even if the world is closed, this gives a kind of sense that most diamonds have adapted to the current situation. Others can take care of their responsibilities like work, home, and keep studying. Higher education will become affordable and accessible instead of moving from one city to another. Dr. Majd suggested that education would be accessible to everyone regardless of age, gender, or economic status. (Magd, 2021)

E-learning removes many complexities that college students face all over the world. Struggle planning, the need to reach the most excellent teacher due to financial or geological conditions, since most students go through stages of shame within the classroom, especially when presenting projects and doing the presentation, in addition to course readings, they are at present a thing of the past for Omani youth and other student in most parts of the world ( Slimi, 2020)

In e-learning, there are many obstacles that may address this sector, and there are several complications in students' use of e-learning, as well as social concerns, computer discomfort for students, and the wide preparation of teachers in online learning management systems (Phama, HiepHung ; Hanh Ho, Tien-Thi-;, 2020).

A study from Oman(Al Musawi, 2010) highlights the plausibility of advertising programs through elearning in expansion to the traditional approach. The think about concluded that students and teachers are Realizing the significance of e-learning and the must be compelled to survey the guidelines some time recently getting a tall score the level of e-learning, particularly when it comes through the application. (Kothaneth, 2020)stated that the student can study anytime and any wear. The utilize of learning and instructing stages can be created in a way that is suitable for both Teachers and students, counting communication aptitudes, and consider plans incorporate Waltz will contribute to Effective learning. Be that as it may, a few students may be adversely influenced, depending on their learning styles, but they must be bargain with this setting and learn other approaches to think about.

\section{RESEARCH OBJECTIVES}

The Objective for this study is:

$>$ To Study and investigate the different types of online teaching and learning strategies used during the COVID-19 pandemic.

$>$ To Study and explore how the COVID and pandemic, affected students' views of online teaching and learning.

$>$ During the COVID-19 pandemic, discuss the difficulties students face in transitioning to online teaching and learning.

$>$ To Study the impact of COVID-19 on education. and to Investigate the different challenges hindering continuing / online education during the COVID-19 lockdown.

$>$ To assess students' perception of online and learning their willingness and unwillingness to learn online. 


\section{SCOPE OF THIS STUDY}

In this project, a research study is conducted on the students of Middle East College -Muscat, Sultanate of Oman on the impact of the Corona pandemic on the education sector and the challenges and difficulties faced by the students and how their learning enriched during pandemic times.

\section{SigNificant OF THE STUDY}

According to this study, most educational institutions have been forced to choose between closing their doors or teaching online due to the new conditions imposed by the COVID-19 pandemic (Murphy, 2020). As a result, many institutions had no choice but to turn to online tutoring to meet their obligations and stay in business. This research paper primarily focuses on online education as well as educational experience to explore problems, opportunities, and potential solutions in Oman. Essentially, in conclusion, the paper looks at the difficulties and opportunities of online learning, as well as recommendations for a better online education system in Oman.

\section{Limitation OF THE STUDY}

Although this project has been strategically planned to meet the goals, it does have some weaknesses and flaws. First and foremost, the project was completed in two stages over the course of seven months. The researcher does not have enough time to review the effect of the Corona pandemic on the education sector and to consider the public issues that this sector faces in seven months, study is restricted to the students from Middle East College only.

\section{RESEARCH METHODOLOGY}

\subsection{Research Design}

The descriptive research design used aiming for a suitable framework for a think about. An awfully critical choice in investigate plan prepare is the choice to be made with respect to investigate approach since it decides how significant data for a ponder will be gotten; be that as it may, the inquire about plan prepare includes numerous interrelated choices.

\subsection{Data Collection Methods}

Data may be a collection of truths, figures, objects, images, and occasions gathered from distinctive sources. For this research primary data is collected through online questionnaire survey from students of MEC.

\subsection{Questionnaire}

A questionnaire could be apparatus comprising of an arrangement of questions for the reason of gathering data from the respondents. Questionnaires can be thought of as a sort of composed meet. It can be done face-to-face or over the phone, computer, or mail. Questionnaires give a cheap, quick, and generally successful way to get expansive sums of data from an expansive test of individuals. However since research is being conducted during pandemic time's online questionnaires used to collect the required information for conducting the research.

\subsection{Research Result and Data Analysis}

The study aim is to highlight the potential of e-learning technology. Our reasoning pointed to examining the true scope of applying this type of methodology to lockdown conditions such as those caused by COVID-19. The logical and educational community can provide valuable new data about elearning and its real reach in pre-university schools. This personal reasoning is illustrated using openended student questionnaires and semi-structured interviews for instructors, board members, and student families in basic and assistant education. Data collections are intended for advertising. The typical investigation was conducted in agreement with the dimensions of the study by linking the access to and use of innovative assets in the classroom, activating the e-learning technology amid face-to-face education, and finally knowing the effects of its application while it is not accessible.

\subsection{Quantitative Data: (Questionnaire)}

The survey is utilized in case assets are constrained as a questionnaire can be very reasonable to plan and administer and time is an imperative asset which a questionnaire consumes to its most extreme degree, assurance of the protection of the members as members will react truly as it were if their 
character is covered up and secrecy is kept up, and corroborating with other discoveries as surveys can be useful affirmation apparatuses when authenticated with other studies that have assets to seek after other information collection procedures.

\subsection{Student Gender Composition}

Member characteristics Table 1 shows the statistical data of the test. An add up to of 321 college under graduates, both men and ladies, from different levels of study were included these understudies were seeking after different scholastic degrees in different disciplines all through the time limit period in Muscat. A somewhat higher number of ladies (52.02\%) than men $(47.35 \%)$ taken part within the overview, with most members matured between 19 and 23. Most of the members were planning for a bachelor's degree (69.1\%), General foundation Program were (24\%) and Post Graduate student were $(6.9 \%)$.

Table1. Description of the number of the response based on gender

\begin{tabular}{|l|l|l|l|l|l|}
\hline Value Label & Value & Frequency & Percent & Valid Percent & Cum Percent \\
\hline Male & 1 & 152 & 47.35 & 47.65 & 47.65 \\
\hline Female & 2 & 167 & 52.02 & 52.35 & 100.00 \\
\hline & Total & $\mathbf{3 2 1}$ & $\mathbf{1 0 0}$ & $\mathbf{1 0 0}$ & \\
\hline
\end{tabular}

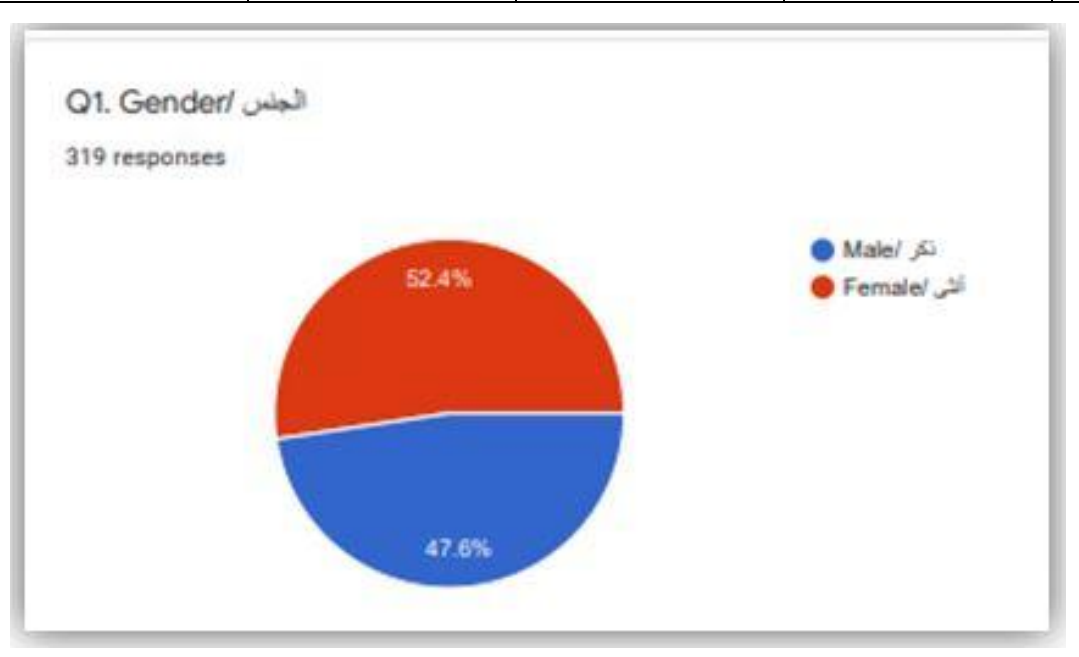

Figure4. Gender based responses

\section{Description of respondent based of the qualification}

Table No. 2 shows the distribution of respondents according to their educational qualifications. can be deduced from the table, $69.09 \%$ of the respondents are undergraduate students and $6.85 \%$ are postgraduate students. While $23.68 \%$ of Foundation Program students. This means that most respondents were undergraduates.

Table2. Description of responses based on the qualification

\begin{tabular}{|l|l|l|l|l|l|}
\hline In which level are you study & Value & Frequency & Percent & Valid Percent & Cum Percent \\
\hline Value Labe & 1 & 22 & 6.85 & 6.94 & 6.94 \\
\hline Master & 2 & 76 & 23.68 & 23.97 & 30.91 \\
\hline $\begin{array}{l}\text { General Foundation } \\
\text { Programme }\end{array}$ & 3 & 219 & 68.22 & 69.09 & 100.00 \\
\hline Undergraduate & & 4 & 1.25 & Missing & \\
\hline & Total & 321 & 100.00 & 100.00 & \\
\hline
\end{tabular}

\section{THE ONLINE E LEARNING AND CAREER EFFICIENCIES}

The table 3 it shows the number of the student those who say that education has an impact on their career lives, and according to the statistics we have reached, that a large number of students, with a rate of $58.26 \%$, say that online learning has affected their career lives, and there are a number of students with a percentage of $87.87 \%$ who said that their professional life will not be affected by the online and there is a group of students who are neutral with a rate of $20.25 \%$. 
Table3. The online e learning and career efficiencies

\begin{tabular}{|l|l|l|l|l|l|}
\hline \multicolumn{2}{|l|}{ Do you think the online class teachings will be helpful for the growth in your career? } \\
\hline Value Label & Value & Frequency & Percent & Valid Percent & Cum Percent \\
\hline Maybe & 1 & 65 & 20.25 & 20.38 & 20.38 \\
\hline No & 2 & 67 & 20.87 & 21.00 & 41.38 \\
\hline Yes & 3 & 187 & 58.26 & 58.62 & 100.00 \\
& & 2 & .62 & Missing & \\
\hline & Total & 321 & 100.00 & 100.00 & \\
\hline
\end{tabular}

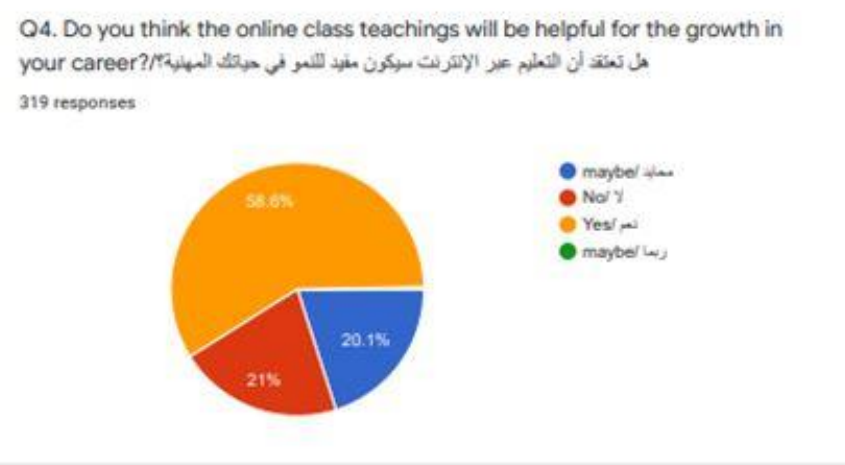

Figure5. The online e learning and career efficiencies

\section{MODE OF STUDY PREFER BY STUDENT}

Table No. 4 shows the statistics of students who wish to continue distance education, as well as the percentage of students who wish to come to the university campus to study.

The largest proportion of them are students who wish to continue distance education, which we conclude that distance education has benefits for students.

Table4. Mode of study prefer by student

\begin{tabular}{|l|l|l|l|l|l|}
\hline Which mode of study do you prefer \\
\hline Value Label & Value & Frequency & Percent & Valid Percent & Cum Percent \\
\hline In Campus & 1 & 141 & 43.93 & 44.20 & 44.20 \\
\hline Online mode & 2 & 178 & 55.45 & 55.80 & 100.00 \\
& & 2 & 062 & Missing & \\
\hline & Total & 321 & 100.00 & 100.00 & \\
\hline
\end{tabular}

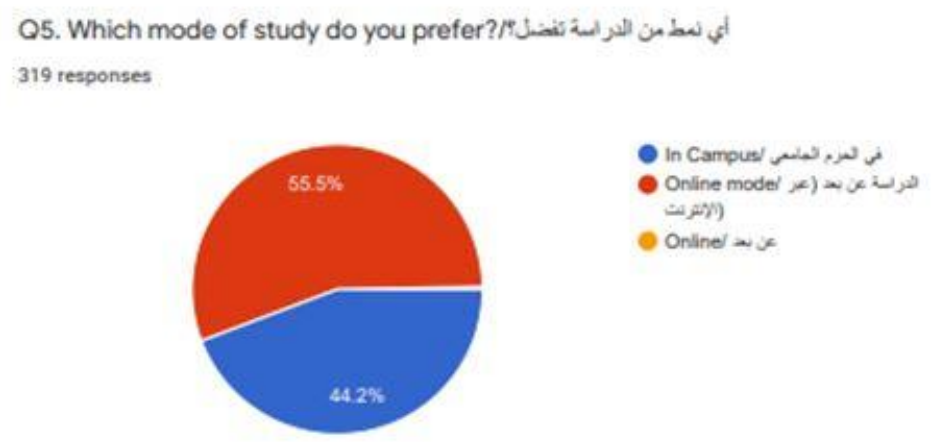

Figure6. Mode of study prefer by student

\section{THE DEVICE DO YOU USE IN E-LEARNING}

There are many current tools used in education: online education software, podcasts, smart boards, smart whiteboards, computer projectors, and multi-tools. We can use these innovative devices to teach in different ways. In this study, we conducted a survey for a group of students about the devices used and we found that the large percentage use aLaptobe, the percentage is estimated at $67.91 \%$. The number of students who use a mobile device is $22.47 \%$, and there are a number of them who use a tablet by $7.79 \%$, while the other group is estimated at $1.25 \%$. 
A Research Study on How the Pandemic Enriched Higher Education System among Students

Table5.The device used in education

\begin{tabular}{|l|l|l|l|l|l|}
\hline What device do you use in education & Frequency & Percent & Valid Percent & Cum Percent \\
\hline Value Label & Value & Fene & 1.25 & 1.25 & 1.25 \\
\hline Other & 1 & 4 & 7.79 & 7.81 & 9.06 \\
\hline Tablet & 2 & 25 & 22.74 & 22.81 & 31.88 \\
\hline Smartphone & 3 & 73 & 67.94 & Missing & 100.00 \\
\hline Laptop & 4 & 218 & .31 & & \\
\hline & & 1 & 100.00 & 100.00 & \\
\hline
\end{tabular}

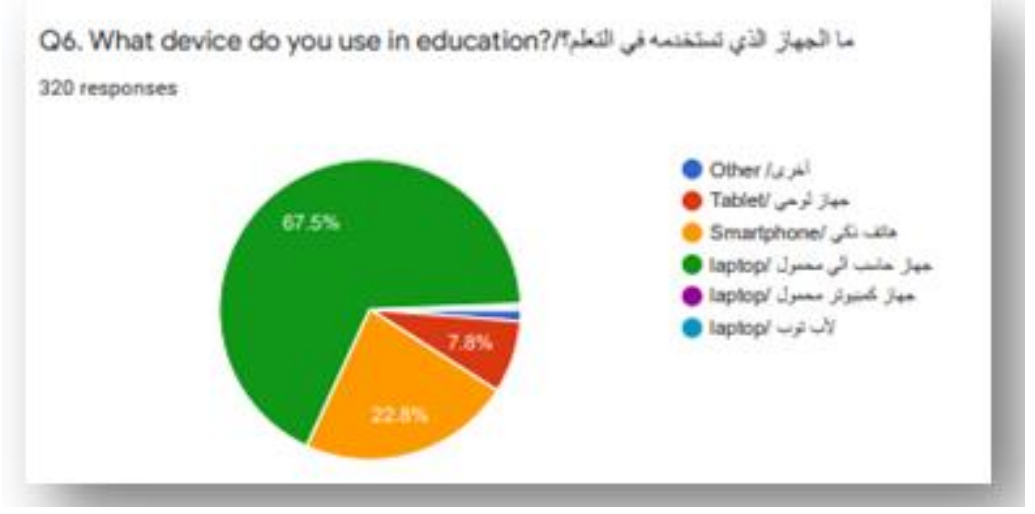

Figure7. The device used in education

\section{STUDENT SATISFACTION LEVEL ON THE SUPPORT PROVIDING BY FACULTY DURING DISTANCE LEARNING}

The active extension of online teaching and learning has been fueled mainly by the rapid development of the web and various web assets, which have had such an enormous impact on the quality of teaching and learning that the use of information technology becomes common knowledge in teaching. A modern method of communication has emerged that is changing the direction of students from face-to-face education to online education. Moreover, the accessibility of removal instructions, course offerings, and the growing number of selected students all speak to the importance of this teaching strategy (Zapalska \& Brozik, 2006).

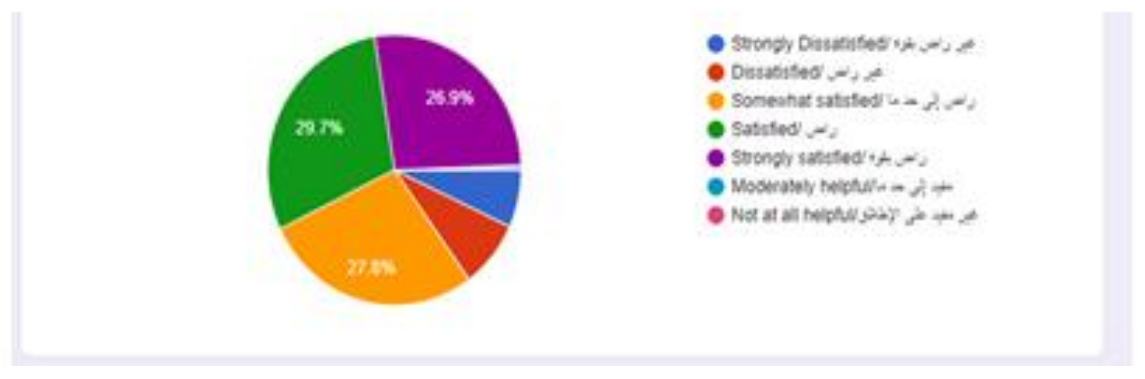

Figure9. Student satisfaction on online learning.

We conclude from this study that the large percentage of students are somewhat satisfied with what faculty members have provided to students during the pandemic, estimated $26 \%$ of students are completely satisfied.

\section{STUDENT SATISFACTION LEVEL ON THE TECHNOLOGY AND SOFTWARE YOU ARE USING FOR ONLINE LEARNING}

According to (State University) On a very basic level, COVID-19 has changed instructions, prompting hundreds of colleges, colleges, schools, and mentors to move educational cost to default settings. While many open teaching and learning spaces are currently being revived, intersecting forms of education are likely to continue for some time. The triumph of this show depends entirely on the innovation chosen for the work and how the teachers adapt to it, So what online tutoring software should you use for a victory for virtual education? 
Through the questionnaire, it was shown that a large percentage of students are completely satisfied with the tools and techniques used in e learning, which we conclude that the techniques used were easy and convenient for the student to understand.

There is another group of students who are satisfied to some extent. As for the students who are not satisfied with the techniques used, their number is small compared to the total number of students.

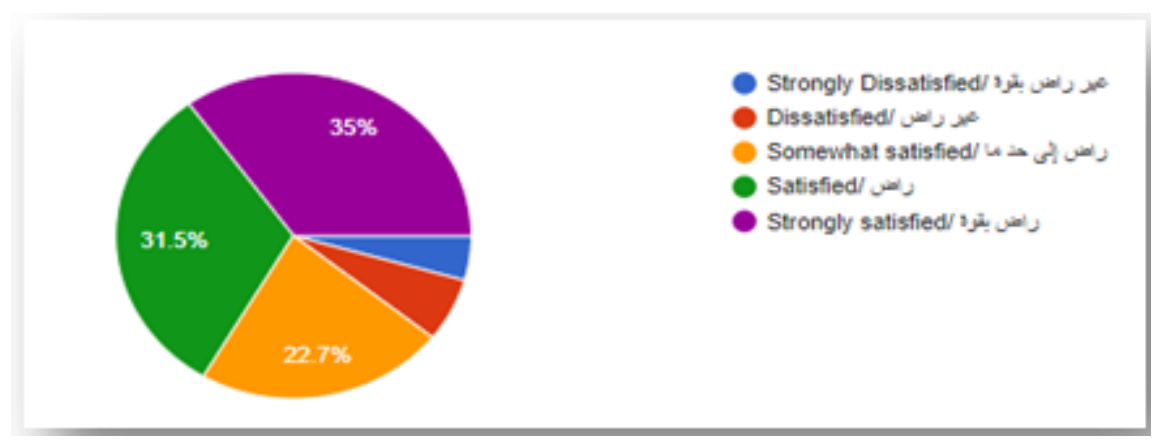

Figure10. Student satisfaction level on the technology and software you are using for online learning

\section{IS COLLEGE LIFE (IN CAMPUS) DIFFERENT FROM DISTANCE EDUCATION?}

Choosing a college to choose is not a straightforward task because everyone needs to go to an educational institution that is known to shine in certain courses. At some point recently you were already thinking about college you just need to go to, it is crucial to decide whether you need to choose an online educational program or an on-campus educational program. Many individuals think about why the model is necessary because the recognition obtained through online instruction is the same as that obtained in on-campus education. It is true that the outcome is the same, but the learning environment is exceptionally distinct within the two phases.

The table below shows the percentage of students who feel their desire to come to the campus to study, as well as students who wish to complete their studies via the Internet.

Table6.College life (in campus) different from distance education

\begin{tabular}{|l|l|l|l|l|l|}
\hline Is college life (in campus) different from distance education \\
\hline Value Label & Value & Frequency & Percent & Valid Percent & Cum Percent \\
\hline Maybe & 1 & 32 & 9.97 & 9.97 & 9.97 \\
\hline No & 2 & 51 & 15.89 & 15.89 & 25.86 \\
\hline Yes & 3 & 238 & 74.14 & 74.14 & 100.00 \\
\hline & Total & 321 & 100.00 & 100.00 & \\
\hline
\end{tabular}

\section{RATE THE ONLINE TEACHING}

Through the study we conducted based on the analysis as shown in the table below and the graph .The study was based on a number of students, around 320 students from diffrent program, as it was found that $28 \%$ evaluated online education as excellent, while $22 \%$ estimated it as very good, $25 \%$ as good and $13 \%$ as poor, while a number of students said that online education was Very weak, about $10 \%$.

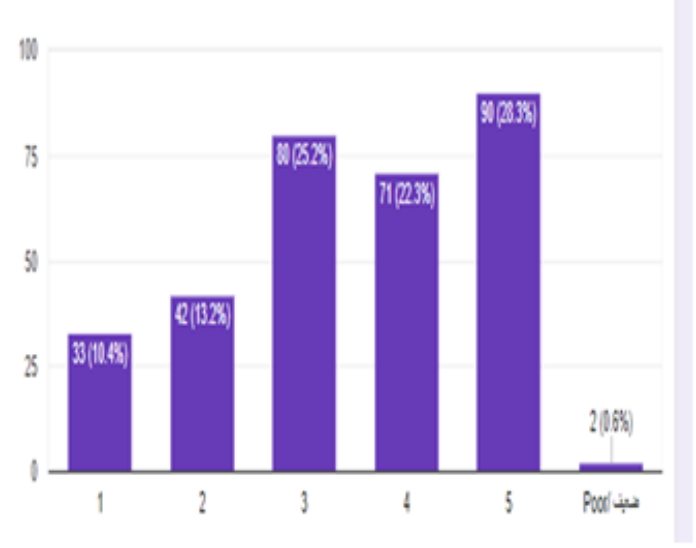

Figure12. Rate the online teaching. 
Table9. Rate the online teaching.

\begin{tabular}{|l|c|c|c|c|c|}
\hline Value Label & Value & Frequency & Percent & Valid Percent & Cum Percent \\
\hline & 1 & 35 & 10.90 & 11.01 & 11.01 \\
\hline & 2 & 42 & 13.08 & 13.21 & 24.21 \\
\hline & 3 & 80 & 24.92 & 25.16 & 49.37 \\
\hline & 4 & 71 & 22.12 & 22.33 & 71.70 \\
\hline & 5 & 90 & 28.04 & 28.30 & 100.00 \\
\hline &. & 3 & .93 & Missing & \\
\hline
\end{tabular}

\section{THE STUDENT OPINION IN HOW THE PANDEMIC AFFECT THE HIGHER EDUCATION SYSTEM}

COVID-19 has widely restricted colleges around the world to indecisively close their campuses and shift the study to online mode. Colleges are not arranged for such a step, and online learning and teaching are constantly advancing. We conducted a study in which we inquired of students about their assumptions about the distinct angles of online education amid widespread developments. We got feedback from 320 students. Students felt that the pandemic affected education by $56 \%$, and of the total number of students, are $27 \%$ of students felt that the pandemic would not affect the education sector, and among them were also neutral students with the percentage of $15 \%$.

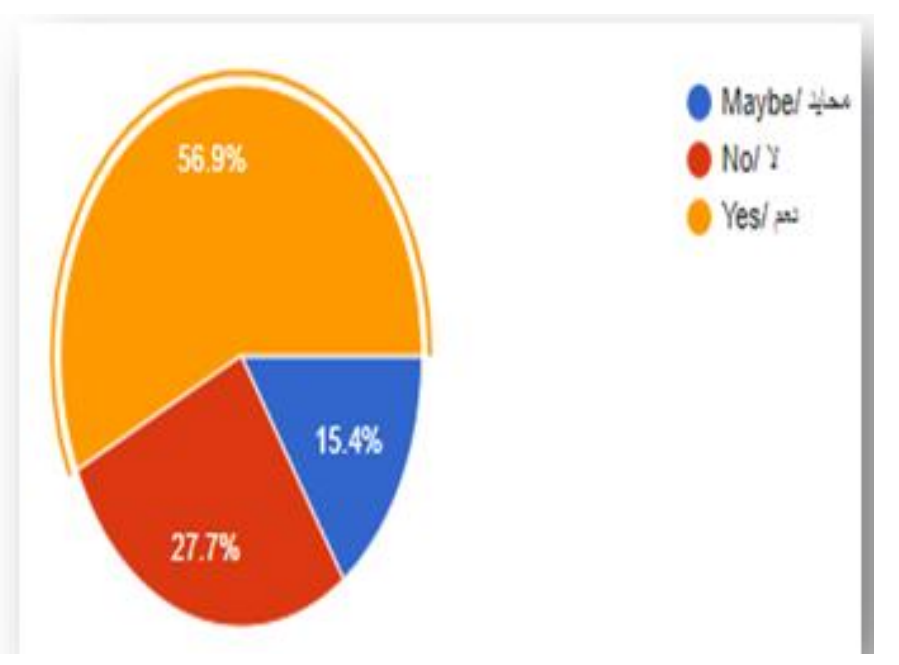

Figure13.The student opinion in how the pandemic affect the higher education system.

\section{CONCLUSION}

Based on the investigation on the information collected the result of the research, According to the number of students answered, students' movement in working the assignments not as it were within the classroom but external of the learning sessions. The most noteworthy number was overwhelmed by the understudies who get to less than 3.5 hours amid the semester. It implies that for the most part the under graduates still not used maximally, the e-learning stage in full filling the composing assignments is partial. The outset conclusion was since number of students' inspiration in learning were still more. It can be concluded that the e-learning stage cannot unravel the issue of limited time in contrast to assembly or routine lessons, Overall satisfaction is acceptable from the perspective of students when it comes to online study during pandemic Covid-19.

\section{RECOMMENDATION}

- To facilitate the learning process in the current pandemic circumstances, the teacher should do asynchronous activities.

- If the teacher feels that some activities require a group of students instead of individual, then he must facilitate the work for the students.

- To enhance online education, teachers must be given easy access and control with the tools available to teach.

- Elements such as video or online activities do not affect the educational level of a student. The teacher may provide some educational clips that contribute to improving the level of the student understanding. 


\section{REFERENCES}

Kantamneni, N., 2020. The impact of the COVID-19 pandemic on marginalized populations in the United States: A research agenda. Elsevier, Volume 119.

Mishra, L., Gupta, T. \& Shree, A., 2020. Online teaching-learning in higher education during lockdown period of COVID-19 pandemic. International Journal of Educational Research Open, Volume 1.

Sintema, E. J., 2020. Effect of COVID-19 on the Performance of Grade 12 Students: Implications for STEM Education. Eurasia Journal of Mathematics, Science \& Technology, 16(7).

Slimi, Z., 2020. Online learning and teaching during COVID-19: A case study from Oman. International Journal of Information Technology and Language Studies, 4(2), pp. 44-56.

Al Musawi, A. S., 2010. E-Learning from an Omani Perspective, Muscat: Researchgate.

Al-Amrani, Said Nasser; Harrington, Michael ;, 2020. The Impact of Online Social Presence on Omani Female Students' Willingness to Communicate in English. Computer-Assisted Language Learning Electronic Journal, 21(2), pp. 220-237.

Al-Mamari, Sumaia; Al-Zoubi, Suhail ; Bakkar, Bakkar ; Al-Mamari, Khawla ;, 2020. Effects of a Training Module on Omani Teachers' Awareness of Gifted Students with. Journal of Education and e-Learning Research, 7(3), pp. 300-305.

Al-Maroof, Rana Saeed ; Salloum, Said A. ; Hassanien, Aboul Ella ; Shaalan, Khaled ; 2020. Fear from COVID-19 and technology adoption: the impact of Google Meet during Coronavirus pandemic. Journal of Interactive Learning Environment, 1(1).

Amoah, Padmore Adusei ; Mok, Ka Ho;, 2020. The COVID-19 Pandemic and internationalisation of higher education: International students' knowledge, experiences, and wellbeing. Emerald Publishing .

Essa, M. M., 2020. Possible role of tryptophan and melatonin in COVID-19. International Journal of Tryptophan Research, Volume 13.

Kothaneth, L., 2020. E-learning is here to stay. Oman Observer, 15 April .

Magd, H., 2021. The effect on Corona virus on teaching and learning [Interview] (22 June 2021).

Murphy, . M. P. A., 2020. COVID-19 and emergency eLearning: Consequences of the securitization of higher education for post-pandemic pedagogy. Contemporary Security Policy, 41(3), pp. 492-505.

Phama, Hiep-Hung; Hanh Ho, Tien-Thi-;, 2020. Toward a 'new normal' with e-learning in Vietnamese higher education during the post COVID-19 pandemic. Higher Education Research \& Development, 39(7).

Pokhrel, Sumitra ; Chhetri, Roshan ; 2021. A Literature Review on Impact of COVID-19 Pandemic on Teaching and Learning. Higher Education for the Future, 19 January, 8(1), pp. 133-141.

Pokrovskaia, Nadezhda N. ; Leontyeva , Veronika L. ; Ababkova, Marianna Yu.; Cappelli, Lucio ; D’Ascenzo, Fabrizio;, 2021. Digital Communication Tools and Knowledge Creation Processes for Enriched Intellectual Outcome-Experience of Short-Term E-Learning Courses during Pandemic. Future Internet, 13(43).

Shachar, Mickey ; Neumann, Yoram ; 2003. Differences Between Traditional and Distance Education Academic Performances: A Meta-Analytic Approach. The International Review of Research in Open and Distributed Learning,.

Citation: Haitham Hilal Al Busaidi \& Dr. Syed Aulia “A Research Study on How the Pandemic Enriched Higher Education System among Students" "International Journal of Managerial Studies and Research (IJMSR), vol 9, no. 9, 2021, pp. 32-40. doi: https://doi.org/10.20431/2349-0349.0909005.

Copyright: (C) 2021 Authors. This is an open-access article distributed under the terms of the Creative Commons Attribution License, which permits unrestricted use, distribution, and reproduction in any medium, provided the original author and source are credited. 